\title{
The Troubling Epidemic of Wife-Battering in Ogbaru and Onitsha North Local Government Areas of Anambra State, Nigeria
}

\author{
AREH, Chinwe Edith ${ }^{1}$, Benjamin Okorie Ajah" ${ }^{2}$, Oguejiofo C.P. Ezeanya ${ }^{3}$, EZE, Ann \\ Ugomma $^{2}$, Stanley Ikenna Onwuchekwe ${ }^{1}$ and Chukwuemeka Dominic Onyejegbu ${ }^{4, *}$
}

\author{
${ }^{1}$ Department of Criminology and Security Studies, Chukwuemeka Odumegwu Ojukwu University, Anambra \\ State, Nigeria \\ ${ }^{2}$ Department of Sociology and Anthropology, University of Nigeria, Nsukka \\ ${ }^{3}$ Humanities Unit, School of General Studies, University of Nigeria, Nsukka \\ ${ }^{4}$ Social Sciences Unit, School of General Studies, University of Nigeria, Enugu Campus, PMB $=410002$, \\ Enugu State, Nigeria
}

\begin{abstract}
Purpose: Debates and assumptions on the trend, motives/causes and implications of wife-battering in Nigeria are largely speculative. The purpose of this article is to explore in a raw form, the socio-economic determinants of wifebattering, on the sub-areas of family violence.

Methods: Using qualitative and quantitative research methods, a sample of 364 respondents comprising 196 males and 168 females was drawn from Anambra State, Nigeria. Multi-stage and purposive sampling techniques were used to reach the respondents. Questionnaire and in-depth interviews were instruments for data collection.

Results: Findings confirmed that wife-battering in Ogbaru and Onitsha-North Local Government Areas is most often caused by denial of sex and infidelity.

Conclusion: The policy implications calls for the creation of local government welfare units to be holding periodic talk shows for married couples on the imperative of living happily.
\end{abstract}

Keywords: Denial of sex, Epidemic, Infidelity, Welfare-units, Wife-battering.

\section{INTRODUCTION}

In patrilineal societies, a man's home is often regarded as his "castle" and whatever he does within the privacy of the home often escapes public scrutiny. Wife-battering is a form of domestic violence. Very often, it occurs behind closed doors within families and almost always leads to crises. To some people, it is actually a manifestation of unequal power relations between men and women. It is also often seen as a cultural universal (Gurmu \& Endale, 2017; Hassan, Seedhom \& Mahfouz, 2016; Ajayi, 2015; Abbasi, Akram \& Manzoor, 2015; Onwe, Odo \& Eze, 2019). In other words, it is not limited to any nation or race. However, the degree or frequency of its occurrence may differ from one society to another.

For centuries, unlucky women have been subjected to the whims and brutality of their husbands. Battering is the major cause of injury to women. It is more rampant than auto accidents, rapes or muggings (Oyediran, 2016). Findings have indicated that twothirds of the women in Nigeria are believed to have

*Address correspondence to this author at the Social Sciences Unit, School of General Studies, University of Nigeria, Enugu Campus, PMB $=410002$, Enugu State, Nigeria; E-mail: onyejegbudominic@gmail.com experienced physical, sexual or psychological harm in the family. Again, three out of every 10 women suffer domestic violence from family members (Olatunji, 2017; Ebisi, 2016; Mayaki \& Choji, 2011; Ajah, 2018; Ajah \& Okpa, 2019).

Wife-battering is a gender-based violent act. It could be psychological or physical in nature. A man who batters his wife does so with the intention of controlling her and showing that he is superior to her. He does so by inflicting fear or pain on her. This act is common amongst men who still believe that they have the right to rule and control women. Though a man may have authority over his wife and the wife is expected at all times to obey rules from her husband, some men have misinterpreted this. These kinds of men beat their wives as often as possible in order to prove their superiority and make them subordinate to them (Ebisi, 2016; Mayaki \& Choji, 2011; Ajah, Uwakwe, Nwokeoma, Ugwuoke \&, Nnamani, 2020; Nnam, Effiong, lloma, Terfa \& Ajah, 2021).

The Convention on Preventing and Combating Violence Against Women and Domestic Violence (CPCVAWDV, 2005) sees domestic violence as all acts of physical, social, psychological, or economic violence that exist within the family or between former or current 
spouses or partners, whether or not the perpetrator shares or has shared the same residence with the victim.

It is worthy to note that violence at the domestic arena could be either against women or men but the prevalence varies. While men tend to be attacked and killed by strangers or casual acquaintances, women are most at risk at home or in society with men or other family members (Oyediran, 2016; Oli, 2012; Ugwuoke, Ajah \& Onyejegbu, 2020). In Nigeria, as in some other African countries, family is the primary institution through which every individual is socialized, and the general attitude and common belief is that regardless of type of family, (nuclear or extended), it is the haven of love, security, safety and tranquility (Suaad, 2015; Olumeri, 2015). Everyone is first considered a member of a family before being recognized as a member of any other group or the society in general. Boys grow up to be men "like their fathers" and girls to be women "like their mothers" (Nwabunike \& Tenkorang, 2015).

Surprisingly, the family appears to be a place where lots of oppression, violence and exploitation also occur, instead of love and care (Igwe, 2015). Thus, Igwe sees the family as one of the least safe places for women and children. This form of domestic violence involves overt physical force or violence, emotional or psychological abuse, sexual abuse, verbal abuse, threats and intimidations, economic coercion etc. perpetrated by a husband against the wife.

Culturally, most societies in the past had given men the legal rights to use violence to "discipline" their wives (Eze, Obi \& Ajah, 2020). For instance, during the reign of Romulus in Rome, wife beating was accepted and condoned under "The Laws of Chastisement". Furthermore, Eze, Obi and Ajah noted that the laws of chastisement was adopted into the tradition of the English Common Law as represented in "The Rule of Thumb", where it was accepted that husbands are permitted by law to beat their wives with a rod or switch as long as its circumference is no greater than the girth of the base of the man's thumb. Oli, Igbo and Okoye (2013) argued that violence against women by male partners is widely condoned by many African culture as a result of the belief that chastising a woman by whatever means is embedded in the culture. This then implies that it is regarded as a normal and socially acceptable practice since the culture encouraged it. Traditional practices and beliefs regarding the subordination of women exacerbate the issue of violence against women (Oli, Igbo \& Okoye, 2013).
One of such practices is patriarchy. Further still, Oli, Igbo and Okoye (2013) observed that the traditional Nigerian society is patriarchal, which tends to tolerate violence against women in communities where women are assigned inferior roles, subordinate to the male head of their families, and effectively the properties of their husbands. Also, Dickstein as cited in Oli (2012) noted that the tradition of male dominance or patriarchy has lent credibility to the continuous perpetuation of violence against females by males in the society. Patriarchy among Africans was typically captured in the famous book "Things Fall Apart" in the following conversation between Ezeani (the chief priest) and Okonkwo: "your wife was at fault but even if you entered into your Obi (clan) and found her lover on top of her, you would have committed a great evil to beat her during the week of peace. The evil you have done can ruin the whole clan. The earth goddess whom you have insulted may refuse to give us her increase and we shall all perish" (Eze, Obi \& Ajah, 2020).

Eze, Obi and Ajah (2020) opine that domestic violence as a result of patriarchal system is one variable in a complex constellation of causes which amongst others include poverty, unemployment, socioeconomic and cohabiting status. The advent of modernity has seen the entrance of more and more women into the labour market. For Oli, Igbo and Okoye (2013), a woman's employment status has critical symbolic importance as it signifies a challenge to the culturally prescribed norm of male dominance and female dependence. Where a man lacks this sign of dominance, violence may be a means of reinstating his authority over his wife. Several studies such as Oli (2012), Krafsky and Jason (2013) have argued strongly in favour of the advent of modernity which brought about several social and cultural changes. Such changes include: change in the size of the family, change in the location of the family, occupational differences between the spouses, property acquisition relation between the spouses, double standard of morality for both males and females, authority structure that revolves around the family and technological innovations and social networking. These changes are considered as great indicators that influence wife battering today.

Oli (2012) argued that in the traditional Nigerian society there existed a traditional family support system which while recognizing male dominance equally sought to protect all members from aggression. However, this system is now on the decline largely due to pressures of modernity. For instance, the practice 
whereby relations of the wife will stop at nothing short of beating the hell out of a son-in-law who decides to turn his wife (their daughter, sister) into a punching bag is fast disappearing. Therefore, with the progressive erosion of traditional family support system, there appears to be an increase in domestic violence in modern Nigerian society. Similarly, Emegwa, Lawoko and Jansson (2016) also noted that people are almost witnessing the breakdown of the traditional extended family into its nuclear units; nuclear family consisting of father, mother and children living in segregated walls of "flats" in urban centers where there is no collective or extended family protection of the woman in situations of aggression.

Also, in the views of Oli, Igbo and Okoye (2013), education offered women the ladder to climb in societies as never before. Women now take up roles and job opportunities exclusively reserved for men before. Additionally, Oli, Igbo and Okoye (2013) argued that educational qualification gives women opportunities of grabbing occupations with highly paid income at their disposal which helps them to acquire properties like land, which they were denied in a male dominated society or patriarchal society. While contributing, Eze, Obi and Ajah (2020) lamented that the double standard of morality of our culture, which has great support from the patriarchal nature of our society creates room for wife-battering. This, according to her, explains why matrimonial vows are violated by men. Extra marital affairs by men are often tolerated and accepted by the society, but in situations where the women are involved, it will not be tolerated.

More so, Krafsky and Jason (2013) opine that social networking has created room for increase in wifebattering: "ever since the internet has become a regular part of the human experience, cyberspace has been implicated as an influential factor in online extra marital affairs, real life adultery and breakup of marriages. Thus, every new online fad has become the stories of spouses wandering away from their marriages to a new cyber lover. The media have spotlighted tales and trends of online affairs starting through Chatrooms, Myspace, Second life, Twitter, 2go, Online forum, Facebook etc. These have become threats to many marriages (Krafsky \& Jason, 2013:7).

Statistics have shown that every year in the United States of America, at least 1,000 to 1,600 women die at the hands of their male partners, often after a long, escalating pattern of battering. This estimated number of deaths due to intimate partner violence does not include those women who kill themselves to exit violent relationships, or who die homeless on the streets in their attempt to avoid violent husbands (Ebisi, 2016; Abayomi \& Olabode, 2013). Also, studies from around the world have shown that $10 \%$ to over $50 \%$ of women reported having been hit or otherwise physically harmed by an intimate male partner at some point in their lives (World Health Organization, 2015).

In Nigeria, it is estimated that one in every five women faces some forms of violence during her life time leading to serious injury or death in some cases (Fakunmoju, Bammeke, Oyekanmi, Temilola \& George 2016). Indicating the seriousness of the problem, Oli, Igbo and Okoye (2013) noted that over 5,000 women marched on the streets of Lagos State on $22^{\text {nd }}$ April, 2009 to protest incessant violence against women in the state. In Anambra State, there is a dark-figure on wife-battering statistics of the state. This is unconnected to victim blaming, stigmatization, cultural beliefs, poor and unprofessional attitude of the police/criminal justice system, as well as preference to the informal institutionalized mechanisms like the religious institution for settling of such cases (Obiozor, 2013).

Wife-battering varies in scope from one society to the other. Much of this violence inflicted on women by husbands can make the home one of the most unsafe place for a woman to be (Oli, Igbo \& Okoye, 2013). This phenomenon transcends class, culture and lines of income (Ikenna, 2016; Oli, 2012). International recognition of wife-battering is reflected in the Beijing Declaration and Platform for Action adopted in 1995 at the fourth World Conference on women in Beijing. Nigeria sent the third largest national delegation to this gathering. The various participating governments were urged to work towards the elimination of all forms of sexual harassments, exploitation, trafficking, harmful traditional and customary practices and rape (Oli, 2012). Surprisingly, Nigeria and other African countries are yet to fully implement and domesticate the recommendations agreed upon.

A lot of research efforts have been directed towards the elimination of domestic violence (see Oli, 2012; Krafsky \& Jason, 2013; Nnam, Ajah, Arua, Okechukwu and Okorie, 2019; Ajah, Ajah \& Obasi, 2020; Eze, Ajah, Nwonovo \& Atama, 2021; Anthony, Obasi, Obi, Ajah, Okpan, Onyejegbu, Obiwulu \& Onwuama, 2021) and its impacts in Nigeria. These have been spearheaded by scholars, students, government officials, nongovernmental organizations and other bodies with 
interests in social order. Robust studies in understanding the troubling epidemic of wife-battering in Ogbaru and Onitsha North Local Government Areas of Anambra State, Nigeria is missing. This paper intends to fill this gap and additionally recommend ways of addressing wife-battering.

\section{METHOD}

\section{Study Design and Location}

This study adopted a cross-sectional survey research design which is considered appropriate because it has the capacity to accurately gather necessary information within a limited timeframe on large sample. The design is economical and focuses on studying large and small populations with emphasis on relative incidence, distribution and interrelations of sociological and psychological variables (Eze, Obi \& Ajah, 2020; Areh, Onwuama \& Ajah, 2020). The study was conducted in Onitsha North and Ogbaru Local Government Areas of Anambra State, Nigeria.

\section{Participants and Procedures}

The target population for this study was 349,235 which comprised of 182,714 males and 166,521 females. Of this population, 125,918 are from Onitsha North Local Government while 223,317 are from Ogbaru Local Government (National Population Commission, 2006). Using Alien Taro Yamane (1967) method of sample size determination, with a $95 \%$ confidence level and level of maximum variability $(P=$ $0.05)$, a sample of 400 was computed-out of which364 respondents were finally used after data collation, gleaning, cleansing and analysis.

The multi-stage sampling technique that involves successive random sampling was adopted in the selection of respondents from the communities, villages, streets and households. Multi-stage method is relevant to this study because the population is made up of several clusters: communities, villages, streets and households. The researchers clustered Anambra State into her 21 LGAs which were further grouped into urban and rural LGAs. From this categorization, two LGAs were purposively selected. In this light, Onitsha North LGA was purposively selected from the urban LGA, while Ogbaru LGA was purposively selected from the rural LGA. The essence of choosing these LGAs is because of high prevalence of wife battery in these selected LGAs.

\section{Data Collection and Procedures}

This study adopted mixed methods of scientific enquiries, following quantitative and qualitative approaches in its data collection. The instruments for data collection were structured questionnaire and unstructured 'In-Depth Interview (IDI).' The research instruments were administered by four researchers. Participation in the research was risk-free, anonymous, voluntary, confidential and based on informed consent of all participants. Ethical clearance was obtained from Ethical Committee of the Nnamdi Azikiwe University Teaching Hospital. Of the 400 questionnaires distributed, 364 were returned; 19 of them were not properly completed and thus were rejected while 17 were not returned. Thus, we had a total of 364 copies for analysis. In order to complement data generated through questionnaire instrument, in-depth interviews were conducted on 10 participants - 5 male and 5 female participants respectively. Each respondent's interview lasted between 33 and 80 minutes. The interview was recorded with tape-recorder and handwritten notes.

\section{Data Analysis}

Both qualitative and quantitative components of the data collected were subjected to scrutiny before cleansing, coding and analysis. The quantitative data analysis was performed using International Business Machine (IBM) Statistical Packages for Social Sciences (SPSS) version 20. Utilizing descriptive statistics, the results of IBM SPSS were further analyzed, interpreted and organized using tables, frequencies and charts. The qualitative data were analyzed using manual thematic method, where the responses were transcribed with some catchy phrases retained in their original versions and contexts in the form of extracts or excerpts (see the result section for details).

\section{RESULTS}

Table 1 shows the frequency distribution of respondents on what they consider as the social factor that causes wife-battering in the study areas. The study identified 'denying of sex to a husband' $33(9.1 \%)$ Onitsha North and 38 (10.4\%) Ogbaru as the leading cause of wife battering. This was followed by the view that 'infidelity (engaging in extra marital affairs)' was another major factor leading to wife battering: 33 $(9.1 \%)$ Onitsha North and $31(8.5 \%)$ Ogbaru. This was followed by $20(4.3 \%)$ and $32(9.0 \%)$ from both Onitsha North and Ogbaru respectively that inability of a 
Table 1: Distribution of Respondents by their Opinion on what they Consider as the Social Factors that Causes Wife Battering

\begin{tabular}{|c|c|c|c|c|c|}
\hline \multirow{2}{*}{ Social factors influencing wife battering } & \multicolumn{2}{|c|}{ Onitsha North } & \multicolumn{2}{|c|}{ Ogbaru } & \multirow[t]{2}{*}{ Total } \\
\hline & $\mathbf{F}$ & $\%$ & $\mathbf{F}$ & $\%$ & \\
\hline Lack of respect for husband & 16 & 4.4 & 16 & 4.4 & 32 \\
\hline Infidelity (Engaging in extra marital affairs) & 33 & 9.1 & 31 & 8.5 & 64 \\
\hline Nagging & 9 & 2.7 & 12 & 3.1 & 21 \\
\hline A woman having too many engagements outside the home & 11 & 3.1 & 3 & .7 & 14 \\
\hline Online chatting with unknown persons to the husband & 16 & 4.4 & 6 & 1.6 & 22 \\
\hline Wife paying little attention to the children and domestic chores & 10 & 3.3 & 7 & 1.4 & 17 \\
\hline Inability of a woman to give birth to a male child & 20 & 4.3 & 32 & 9.0 & 52 \\
\hline A woman's inability to cook for her husband & 19 & 3.5 & 26 & 8.9 & 45 \\
\hline Male Chauvinism/Patriarchy & 2 & .6 & 4 & 1.0 & 6 \\
\hline Denying sex to the husband & 33 & 9.1 & 38 & 10.4 & 71 \\
\hline Office dating by a wife & 13 & 3.7 & 4 & 1.0 & 17 \\
\hline Others & 2 & .5 & 1 & .3 & 3 \\
\hline Total & 184 & 49.7 & 180 & 50.3 & 364 \\
\hline
\end{tabular}

Source: Field Survey, 2019.

woman to give birth to a male child' in her family leads to wife battering. Summarily, the findings revealed that most wives are battered as a result of their denying their husbands sex, infidelity (engaging in extra marital affairs) and inability of a woman to give birth to a male child.

According to the response of one of the IDI respondents:

It is usually out of anger and provocation that most men beat up their wives. Madam, the problem is that most of you women don't understand how a man feels when he notices that his own wife is cheating on him. Though I promised my wife I won't beat her, but I have also warned her that any day I find out she is cheating on me, she won't find it funny with me. Apart from cheating, I think this attitude of disrespecting a husband is also a reason. Why should a woman talk when the husband is talking? That is very bad, because two captains cannot stir one ship. In our lgbo culture a woman is not even supposed to be heard... (laughs). So when she now decides to be heard more than the husband, beating becomes a social control mechanism to enforce our norms (IDI: Igwe, Ogbaru).
Another IDI respondent further stated:

This issue of wife battering is very sensitive. Most women have lost their lives as a result of it, and in most cases the women are often blamed. To be honest, most men beat up their wives as a result of alcoholism. A man who is drunk has lost his sense of judgment and at the slightest provocation can turn violent, may be the woman may even be trying to help him but he will beat her trying to prove that he is in control (IDI, Social Welfare Officer, Onitsha North).

From the findings, answer to research question number one is that the social factors influencing wife battering includes 'denying of sex to a husband' Onitsha North 33 (9.1\%) and Ogbaru 38 (10.4\%), 'infidelity (engaging in extra marital affairs)' 33 (9.1\%) and $31(8.5 \%)$ for Onitsha North and Ogbaru respectively, inability of a woman to give birth to a male child is an equally identified social factor Onitsha North $20(4.3 \%)$, Ogbaru $32(9.0 \%)$, a woman's inability to cook for her husband, online chatting with unknown persons to the husband, lack of respect for a husband, office dating by a wife, a woman having too many engagements outside the home etc. Theoretically, Engels, Marx's position is that the family is a social arrangement created by man which provides the 
Table 2: Distribution of Respondents by their Opinion on Economic Factors Influencing Wife Battering

\begin{tabular}{|c|c|c|c|c|c|}
\hline \multirow[t]{2}{*}{ Economic factors influencing wife battering } & \multicolumn{2}{|c|}{ Onitsha North } & \multicolumn{2}{|c|}{ Ogbaru } & \multirow[t]{2}{*}{ Total } \\
\hline & $\mathbf{F}$ & $\%$ & $\mathbf{F}$ & $\%$ & \\
\hline Poverty (Economic hardship) & 35 & 12.3 & 33 & 6.4 & 68 \\
\hline Unemployment & 30 & 7.0 & 13 & 4.8 & 43 \\
\hline Unnecessary financial demand by a wife & 18 & 5.4 & 24 & 6.1 & 42 \\
\hline Frivolous spending by a wife & 7 & 2.0 & 5 & 1.3 & 12 \\
\hline Engaging in work that take a wife away from home for a very long time & 44 & 15.5 & 34 & 5.9 & 78 \\
\hline Wife accepting monetary or material gifts from men & 49 & 14.9 & 66 & 16.7 & 115 \\
\hline Other & 1 & 6 & 5 & 1.0 & 6 \\
\hline Total & 184 & 57.7 & 180 & 42.2 & 364 \\
\hline
\end{tabular}

Source: Field Survey, 2019.

foundation of the unequal relationship between men and women. The argument is that the family creates a rational basis for women's subordination and therefore the entrenchment of an overwhelming system of dominant and subordinate roles (Ritzer, 1996). In other words, Engels and Marx's position is that it is the material condition of married couples that determines the social conflict they face. Women are disadvantaged in non-industrialized societies in this regard because they depend a lot on their husbands especially during and after childbirth. Men tend to wield some authority as a result. In industrialized societies, social status of women get enhanced when they get paid jobs, removed from rural social structure, some resilient and primordial attributes and values. Violation can be a source of battering, for example, infidelity.

Table 2 shows the frequency distribution of respondents on what they consider as the economic factors influencing wife battering. Respondents in Onitsha North 49(14.9\%) and Ogbaru 66(16.7\%) identified: 'wives accepting money and material gifts from men' as the main reason for battering. This was followed by $44(15.5 \%)$ and $34(5.9 \%)$ from Onitsha North and Ogbaru respectively who attributed it to a wife 'engaging in work that takes her away from home for a very long time' Also, 'poverty (economic hardship)' was identified by $35(12.3 \%)$ Onitsha North and $33(6.4 \%)$ Ogbaru as another leading factor to wife battering. Summarily, the findings revealed that economically, most wives are battered as a result of their accepting money and material gifts from men, they are not married to.

An IDI interviewee stated thus:

I think wasteful spending comes first in this regard, you know there is economic meltdown now, and when a man suffers to get some money and gives same to the wife, he expects her to manage it well; by buying only necessary things. But some women will go ahead and purchase all manner of things especially clothes or make-up kits. If they come demanding for more, the man out of frustration may lash on her. Women who spend too much are prone to be beaten because money is not easy to earn. A woman needs to understand that if her husband is poor, or does not have much money, she should manage what he gives her, and should not emulate other women especially those she may not know what their husbands do for a living (IDI: Igwe, Onitsha North).

Another IDI respondent has a contrary view:

My dear, a wife beater is not a good husband, let us not use the economy as an excuse, what of situations whereby the woman is even the bread winner of the family and the husband still beats her persistently without remorse. Does the economy affect only him, what of his friends on the same job and income level who don't beat their wives? We need to stop hiding on the clouds of economic hardship or excessive demand of money as excuse for wife battering. See, if you don't have money tell her you don't have and go away, don't batter her please! (IDI: Female School Principal, Onitsha North).

From the findings, answer to research question number two revealed that the economic factors 
influencing wife battering includes 'wives accepting money and material gifts from men unknown to their husbands $49(14.9 \%)$ Onitsha North, 66(16.7\%) Ogbaru as the leading economic factor. This was followed by 'engaging in work that takes a wife away from home for a very long time' 44(15.5\%) Onitsha North and $34(5.9 \%)$ Ogbaru. Also, 'poverty (economic hardship)' was identified as another leading factor with $35(12.3 \%)$ Onitsha North and 33(6.4\%) Ogbaru. Other factors are unnecessary financial demand by a wife, frivolous spending by a wife, unemployment etc. Theoretically, this corroborates John Dollard's frustration-aggression theory (1939) which posits that frustration causes aggression, and that when the source of the frustration cannot be challenged, the aggression gets displaced onto an innocent target. Relating this to the study, for example when a husband is unemployed or being confronted by economic hardship that he cannot meet his wife or family needs, instead of confronting the situation or the miserable state, he displays the aggression on the wife by any slight provocation. Economic hardship can be socio-structurally determined for instance when workers are retrenched or exploited, monetary gifts can come from work colleagues because of existing social relations between them and also some paid jobs keep married couples apart. Working class couples are constrained by their occupational roles. All these can be sources of conflict. (Marx; 1820).

Table 4 shows the frequency distribution of respondents in identifying existing institutional mechanism for handling reported incidences of wife battering and the effectiveness of these existing institutionalized mechanisms for handling reported incidences of wife battering in their communities. Respondents from Onitsha North $99(31.0 \%)$ and $72(16.0 \%)$ Ogbaru were of the view that religious leaders such as priests, pastors and Imams are the

Table 3: Distribution of Respondents by their Opinion on the Existing Institutional Mechanisms for Handling Reported Incidences of Wife Battering in Onitsha North and Ogbaru LGAs

\begin{tabular}{|c|c|c|c|c|c|}
\hline \multirow{2}{*}{$\begin{array}{l}\text { Which of these Institutionalized Mechanisms is Commonly used in Settling } \\
\text { Wife Battering in your Area? }\end{array}$} & \multicolumn{2}{|c|}{ Onitsha North } & \multicolumn{2}{|c|}{ Ogbaru } & \multirow[t]{2}{*}{ Total } \\
\hline & $\mathbf{F}$ & $\%$ & $\mathbf{F}$ & $\%$ & \\
\hline Family/Kinsmen & 26 & 6.4 & 31 & 9.3 & 57 \\
\hline Igwe/ His Cabinet & 33 & 9.4 & 52 & 14.0 & 85 \\
\hline Town Union Executives & 13 & 3.4 & 21 & 5.9 & 34 \\
\hline Religious Leaders (Priests/Pastors/Imams etc) & 99 & 31.0 & 72 & 16.0 & 171 \\
\hline Police/Customary Court & 8 & 2.5 & 3 & .5 & 11 \\
\hline Other & 5 & 1.4 & 1 & .2 & 6 \\
\hline Total & 184 & 54.1 & 180 & 45.9 & 364 \\
\hline
\end{tabular}

Source: Field Survey, 2019.

Table 4: Distribution of Respondents by their Opinion on the Effectiveness of Existing Institutional Mechanisms for Handling Reported Incidences of Wife Battering in Onitsha North and Ogbaru LGAs

\begin{tabular}{|c|c|c|c|c|c|c|c|c|c|}
\hline \multirow{2}{*}{$\begin{array}{l}\text { How effective is that } \\
\text { Institutionalized } \\
\text { Mechanism in settling } \\
\text { Reported Wife } \\
\text { Battering Incidences in } \\
\text { your area? }\end{array}$} & \multicolumn{4}{|c|}{ Onitsha North } & \multicolumn{4}{|c|}{ Ogbaru } & \multirow[t]{2}{*}{ Total } \\
\hline & $\begin{array}{c}\text { Very } \\
\text { Effective }\end{array}$ & $\begin{array}{c}\text { Less } \\
\text { Effective }\end{array}$ & $\begin{array}{c}\text { Not } \\
\text { Effective }\end{array}$ & Undecided & $\begin{array}{c}\text { Very } \\
\text { Effective }\end{array}$ & $\begin{array}{c}\text { Less } \\
\text { Effective }\end{array}$ & $\begin{array}{c}\text { Not } \\
\text { Effective }\end{array}$ & Undecided & \\
\hline Family/Kinsmen & 9 & 12 & 3 & 2 & 15 & 0 & 2 & 14 & 57 \\
\hline Igwe/ His Cabinet & 20 & 6 & 2 & 5 & 34 & 8 & 7 & 3 & 85 \\
\hline Town Union Executives & 4 & 1 & 5 & 3 & 9 & 3 & 4 & 5 & 34 \\
\hline Religious Leaders & 56 & 23 & 9 & 11 & 51 & 12 & 3 & 6 & 171 \\
\hline Police/Customary Court & 2 & 7 & 4 & 0 & 1 & 2 & 0 & 1 & 17 \\
\hline \multirow[t]{2}{*}{ Total } & 91 & 49 & 23 & 21 & 108 & 27 & 16 & 29 & \multirow[t]{2}{*}{364} \\
\hline & \multicolumn{4}{|c|}{184} & \multicolumn{4}{|c|}{180} & \\
\hline
\end{tabular}

Source: Field Survey, 2019. 
most commonly used mechanism for settling battering. This was followed by $33(9.4 \%)$ Onitsha North and $52(14.0 \%)$ Ogbaru who said the Igwe (the traditional ruler) and his cabinet members are often consulted for wife battering issues. This was followed by $26(6.4 \%)$ Onitsha North and 31(9.3\%) Ogbaru respondents who said family members and kinsmen also settle wife battering incidences. The study also identified town union executives as one of the institutions with respondents $13(3.4 \%)$ Onitsha North and $21(5.9 \%)$ Ogbaru; while $8(2.5 \%)$ Onitsha North and $3(.5 \%)$ Ogbaru respondents were of the view that the police and customary court is another existing institutional mechanism for handling reported incidences of wife battering in their communities. Summarily the study revealed the effectiveness of the existing institutionalized mechanism for handling reported wife battering incidences, that 56 (Onitsha North) and 51 Ogbaru respondents were of the view that the most effective existing institutional mechanism for handling reported incidences of wife battering is the religious institution. This was followed by the lgwe and his cabinet with 20 and 34 respondents from Onitsha North and Ogbaru respectively. Also 9 and 15 respondents, 4 and 9 respondents, 2 and 1 respondents from Onitsha North and Ogbaru respectively were of the view that family and kinsmen, town union executives, police and customary courts settle reported wife battering incidences.

An IDI interviewee stated:

There are several institutions that perform this responsibility. Here in my palace for example we often settle wife battering disputes. However, I must tell you some women will tell you they want their religious daddy (pastors or priests) to settle it for them. Most times the people do not like going to the police probably because of the stigma attached to it (IDIs: Igwe Onitsha North and Ogbaru).

Another IDI respondents stated:

You know our cultural pattern directly or indirectly prohibits people from speaking up about such issues. Instead, you will be advised to endure, that no family is perfect. So, we at the social welfare office do not really get much of the report of these incidences, perhaps the people do not want to be stigmatized. Honestly, our institution is not very effective in that aspect (IDIs: Social Welfare officers, Onitsha North and Ogbaru).

From the findings, answer to research question three is that the prevalent institutionalized mechanisms for handling reported incidences of wife battering in Onitsha North and Ogbaru LGAs is the informal types, with respondents from Onitsha North 99(31.0\%), $72(16.0 \%)$ Ogbaru who identified the use of Religious Leaders (Priests/Pastors/Imams etc); this was followed by Igwe/His Cabinet $33(9.4 \%)$ Onitsha North and $52(14.0 \%)$ Ogbaru were of that view; Family/Kinsmen followed with 26(6.4\%) Onitsha North, 31(9.3\%) Ogbaru respondents; Town Union Executives were also identified by 13(3.4\%)Onitsha North, 21(5.9) Ogbaru respondents respectively. Notwihstanding, $8(2.5 \%)$ Onitsha North and $3(.5 \%)$ Ogbaru respondents respectively were of the view that the police and customary courts are other existing institutional mechanism for handling reported incidences of wife battering. However, religious institution was identified

Table 5: Distribution of Respondents on their Opinion on how Wife Battering can be Minimized in Onitsha North and Ogbaru LGAs

\begin{tabular}{|c|c|c|c|c|c|}
\hline \multirow[t]{2}{*}{ Possible ways of minimizing wife battering } & \multicolumn{2}{|c|}{ Onitsha North } & \multicolumn{2}{|c|}{ Ogbaru } & \multirow[t]{2}{*}{ Total } \\
\hline & $\mathbf{F}$ & $\%$ & $\mathbf{F}$ & $\%$ & \\
\hline Arrest and prosecution of batterers & 31 & 8.4 & 22 & 6.2 & 53 \\
\hline Awareness campaign on the consequences of battering & 76 & 19.7 & 43 & 13.0 & 119 \\
\hline Strengthening of the judicial system to be more responsive & 21 & 5.8 & 18 & 4.9 & 39 \\
\hline Provide specialized community based services to victims & 6 & 2.4 & 21 & 5.0 & 27 \\
\hline Sensitization on why victims should speak up & 36 & 8.7 & 50 & 14.9 & 86 \\
\hline Change in institutionalized cultural practices like patriarchy & 14 & 4.1 & 26 & 6.9 & 40 \\
\hline Total & 184 & 49.1 & 180 & 50.9 & 364 \\
\hline
\end{tabular}

Source: Field Survey, 2019 
by 56 and 51 respondents from Onitsha North and Ogbaru respectively as the most effective mechanism for settling reported wife battering incidences.

Table 5 shows the frequency distribution of respondents on what they consider as the best way to eliminate the incidences of wife battering in the study areas. Indeed, 76(19.7\%) Onitsha North and 43(13.0\%) Ogbaru respondents said that there is need for awareness campaign on the consequences of battering, while 50(14.9\%) Ogbaru and 36(8.7\%) Onitsha North respondents were of the view that it is by sensitization on why victims of wife battering should speak up. Also 31(8.4\%) Onitsha North and 22(6.2\%) Ogbaru respondents maintained that arrest and prosecution of batterers will go a long way in reducing the incidences of wife battering. Further, 26(6.9\%) Ogbaru and $14(4.1 \%)$ Onitsha North respondents were of the view that there is need for change in institutionalized cultural practices like patriarchy and $21(5.8 \%)$ Onitsha North, 18(4.9\%) Ogbaru respondents held the view that strengthening of the judicial system to be more responsive will help reduce the occurrences of wife battering. More still, 21(5.0\%) Ogbaru and $6(2.4 \%)$ Onitsha North respondents were of the view that providing specialized community based services to victims will also help in the eradication of wife battering.

According to an IDI respondent:

Look, I have advocated prosecution severally. A person who turns someone's daughter into a punching bag should be prosecuted and if found guilty, jailed. At least, while in jail he will meet his fellow fighters and fight with them while the woman will have some rest (IDI: Igwe, Ogbaru).

Another IDI respondent stated thus:

More awareness is required to curb this issue. Most men are not even fully aware of the dangers inherent in their actions.
Again, most of the women (victims) that keep sealed lips do not as well know they are endangering their lives. They should be encouraged to speak up. Therefore, they should be enlightened the more so as to be able to effect a change (IDIs: Social welfare Officers, Onitsha North and Ogbaru).

From the findings, the answer to research question five is that the incidences of wife battering can be minimized through awareness campaign on the consequences of battering. In their answers, 76(19.7\%) Onitsha North and 43(13.0\%) Ogbaru respondents identified awareness campaign as an important factor. This was followed by $50(14.9 \%)$ Ogbaru and 36(8.7\%) Onitsha North respondents who were of the view that it is by sensitization that victims of wife battering should speak up. Also $31(8.4 \%)$ Onitsha North and 22(6.2\%) Ogbaru respondents maintained that arrest and prosecution of batterers will go a long way in reducing the incidences of wife battering. Further sill, 26(6.9\%) Ogbaru and $14(4.1 \%)$ Onitsha North respondents were of the view that there is need for change in institutionalized cultural practices like patriarchy and 21(5.8\%) Onitsha North, 18(4.9\%) Ogbaru respondents held the view that strengthening of the judicial system to be more responsive, will help reduce the occurrences of wife battering. More still, 21(5.0\%) Ogbaru and 6(2.4\%) Onitsha North respondents were of the view that providing specialized community-based services to victims will help in minimizing the occurrences of wife battering. Theoretically, economic determinism of the Marxian theory plays a major role here in the sense that what will be the fate of a battered woman that speaks up against her husband when she and her children depend on the man for survival. Hence, the call for awareness campaign on the consequences of battering is one of the most important ways of minimizing the incidences of wife battering in our communities.

Table 6: Test of Hypothesis One

\begin{tabular}{|c|c|c|c|c|c|}
\hline \multirow{2}{*}{$\begin{array}{c}\text { Place of } \\
\text { Residence }\end{array}$} & \multicolumn{4}{|c|}{ How often does your partner beat (batter) you? } & \multicolumn{2}{c|}{$\mathbf{X}^{2}$} \\
\cline { 2 - 6 } & Very Often & Often & Sometimes & Not at All & $\boldsymbol{X}^{2}=\mathbf{7 1 . 9 4 5}$ \\
\hline \hline Rural & $162(64.0 \%)$ & $12(21.8 \%)$ & $2(11.8 \%)$ & $35(89.7 \%)$ & $(\mathrm{N}=364)$ \\
\hline Urban & $91(36.0 \%)$ & $43(78.2 \%)$ & $15(88.2 \%)$ & $39(100.0 \%)$ & $\mathrm{df}=3$ \\
\hline Total & $253(100.0 \%)$ & $55(100.0 \%)$ & $17(100.0 \%)$ & .001 \\
\hline
\end{tabular}

Source: Field Survey, 2016 
Table 7: Test of Hypothesis Two

\begin{tabular}{|c|c|c|c|}
\hline \multirow{2}{*}{ Educational level } & \multicolumn{2}{|c|}{ Employment status } & Total $\mathbf{X}^{2}$ \\
& Non paid women & Paid Women & $\boldsymbol{X}^{2}=\mathbf{5 . 1 9 0}$ \\
\cline { 2 - 4 } & $31(16.1 \%)$ & $162(83.9 \%)$ & $193(100 \%)(\mathrm{N}=364)$ \\
\hline \hline Less Educated & $14(8.2 \%)$ & $157(91.8 \%)$ & $171(100 \%) \mathrm{df}=1$ \\
\hline Highly Educated & $45(12.4 \%)$ & $319(87.6 \%)$ & $364(100 \%) \mathrm{P}<.023$ \\
\hline
\end{tabular}

Source: Field Survey, 2016

\section{Test of hypotheses}

\section{Hypothesis One}

'Wives who reside in the rural areas are more likely to be battered than those in the urban centers.'

There is a significant relationship found between place of residence and wife battering at $p<.001$ level of significance.

\section{Hypothesis Two}

Respondents with higher education are more likely to perceive women in paid employment as more prone to battering than those with lower educational level.

Education is found to be statistically significant at $p<.023$ level of significance in perceiving women in paid employment as more prone to battering.

\section{DISCUSSION}

The study findings revealed that diverse views exist among the respondents on the social factors that precipitate wife battering. In Onitsha North and Ogbaru LGAs it is believed by $33(9.1 \%)$ and $38(10.4 \%)$ respondents respectively that a wife 'denying sex to her husband' and acts of 'infidelity (engaging in extra marital affairs)' can lead to wife battering. This was followed by $20(4.3 \%)$ in Onitsha North and $32(9.0 \%)$ from Ogbaru that were of the opinion that 'inability of a woman to give birth to a male child' leads to wife battering. Others are lack of respect for husband, nagging, having too many engagements outside the home, Online chatting with unknown persons to the husband, wife paying little attention to the children and domestic chores, male chauvinism/patriarchy, office dating by a wife etc. These align with Ebisi (2016), Ezeilo (2013) and Kawu (2013) who separately found amongst others, that refusal of sex, disrespect and challenging of a man's authority, having too many engagements outside the home and less attention to children or domestic chores, as well as suspicion of having a sexual relationship outside the home could cause a man to batter his wife. More so, the findings equally corroborate the views of Igwe (2015), Umeh and Akpede (2012), Ajah and Ugwuoke (2018) who found that inability to give birth to a child, especially male child leads to battering. This is true of Nigeria and indeed, most patriarchal societies, where serious premium is placed on male children. Where this expectation is not met; procreation is perceived to have been doomed. There is also a perception among the respondents on the emerging culture of online chatting/dating. This is undoubtedly a possible factor that can lead to battering when the husband is ignorant of the person(s) his wife is frequently communicating with. Suspicion could be raised when she is having too many engagements outside the home. These can lead to wife battering.

On the other hand, the study identified some economic factors that lead to wife battering. Pronounced variables here are a wife's acceptance of monetary or material gifts from men; $49(14.9 \%)$ in Onitsha North and 66(16.7\%) respondents from Ogbaru shared same view. However, this was followed by $44(15.5 \%)$ and $34(5.9 \%)$ respondents from Onitsha North and Ogbaru respectively who attributed wife battering to one's wife 'engaging in work that takes her away from home for a very long time'. Additionally, 'poverty (economic hardship)' were identified by $35(12.3 \%)$ and $33(6.4 \%)$ from Onitsha North and Ogbaru as also a leading factor to wife battering. Others are unemployment, unnecessary financial demand by a wife, frivolous spending by a wife, etc. This is in agreement with the findings of Umeh and Akpede (2012), Ezegbe, Anyanwu, Oyeoku and Abiogu (2013), Slide (2013), Nnamani, Ilo, Onyejegbu, Ajah, Onwuama, Obiwulu and Nzeakor (2021) who separately found in their studies that unnecessary financial requests or demands by the wife, frivolous spending, economic hardship and involvement in works that take them (wives) away for a very long time are major economic factors leading to wife battering.

The study also found that although wife battering prevails in the study areas, there are institutional 
mechanisms for handling the problem. Respondents from Onitsha North $99(31.0 \%)$ and from Ogbaru $72(16.0 \%)$ were of the view that religious leaders such as Priests, Pastors and Imams are the most commonly used mechanism for settling wife battering. This was followed by 33(9.4\%) Onitsha North and 52(14.0\%) from Ogbaru who said the Igwe and his cabinet members are often consulted for wife battering issues. On how effective the mechanisms have been in settling battering, $96(30.5 \%)$ and $79(17.6 \%)$ from Onitsha North and Ogbaru respectively said it was very effective. From the findings therefore, it is clear that the informal mechanisms are most preferred to the formal equivalent in settling wife battering related cases in Onitsha North and Ogbaru LGAs. This confirms the findings of Albert, Herault and Omitoogun (2013), Ajah and Onyejebu (2019); Ajah Dinne and Salami (2020) that the most frequently used channel in settling battering in Nigeria is the religious forum. Preference of religious approach to the resolution of marital conflict like wife battering is an indication of cognitive poverty of those involved. The world is at the moment talking of human rights, equality of the sexes through women empowerment. Many institutions exist to champion the cause of battered women such as Human Rights Commission, International Federation of Women Lawyers (FIDA). The women reverence and adore their religious leaders apparently for being the "mouth piece of God".

On how the rising incidences of wife battering could be reduced, the study found that in Onitsha North $76(19.7 \%)$ respondents said that there is need for awareness campaign on the consequences of battering; respondents from Ogbaru 50(14.9\%) believed that proper sensitization on why victims should speak up will help reduce the menace. Other proposed useful measures found include: 'arrest and prosecution of wife batterers, strengthening of the judicial system to be more responsive, provision of specialized community-based services to victims of wife battering and change of the institutionalized cultural practices like patriarchy'. These agree with the findings of Olatunji (2017), and Suaad (2015) who advocated for awareness campaign on implications of the problem and a social consensus on zero tolerance to wife battering. It is important to note WHO (2014) suggested legal reforms, police proper training and establishment of specialized services for alleviating the problem.

Hypothetically, it was found that a significant relationship exists between place of residence and wife battering at $p<.001$ level of significance. This therefore explains that due to lack of proper exposure or awareness, wives that reside in the rural areas are more likely to be battered than their counterparts in the urban centers. Male dominance syndrome is more pervasive in rural areas. Rural social structure constrains people mechanically. The laws are restrictive. Violation of norms is highly likely to get several banning. Secondly, education was found to be statistically significant at $p<.023$ level of significance to employment effect of wife battering. It therefore implies that respondents with higher education are more likely to perceive women in paid employment as more prone to battering than those with lower educational level. This may not be surprising as feminists will always see their social elevation either through paid jobs as a threat to the men. It may also not be uncommon to hear most men say 'perhaps she is challenging my authority in this house because of that her job or money'; thus, battering may set in.

\section{CONCLUSION AND RECOMMENDATIONS}

Wife battering in Onitsha North and Ogbaru LGAs of Anambra State is associated with variables like: denial of sex to a husband, infidelity (extra marital affairs), inability of a wife to give birth to a male child, a wife's inability to cook for her husband, lack of respect for a husband, having too many engagements outside the home, online chatting/dating, wife paying little attention to the children and others. Economically, they include a wife's acceptance of monetary or material gifts from men, poverty (economic hardship), unemployment, unnecessary financial demand by a wife, frivolous spending by a wife etc. Similarly, prevailing institutionalized mechanisms for settling wife battering are the use of religious leaders (such as Priests/Pastors/Imams etc), family/kinsmen, Igwe and his cabinet, town union executives, Police/Customary Court. Interestingly, the religious institution was found to be the most effective amongst others. Preference for religious approach to the resolution of wife battering could be as result of cognitive poverty of those involved, though there are cases where other reasons were responsible for the choice. Marx saw religion as the opium of the masses and it still remains an institution that makes battered wives accept their unpleasant position in the society because many battered wives and their children are dependent on their batterers (husbands) for survival. Therefore, religious leaders should discourage wives using denial of sex to their spouse as a form of punishment or means of communicating their grievances during 
conflict situations. Extra marital affairs and disrespecting their husbands, especially in public, should be avoided. Husbands should also desist from extra marital sex, they should not batter their wives when they are told to stop having extra marital affairs. Husbands should also understand that it is not a woman that determine the sex (gender) of the baby she will give birth to. Hence, whether a male or female child, it should be appreciated accepted.

Similarly, local governments' welfare units should be created and empowered to be holding periodic talk shows for married couples on the importance of living happily. Willing couples should be taught how to select the sex of a baby; effective communication of their daily experiences to each other, how to manage their external image etc. Government should help battered wives to get emotionally stabilized. They should ensure that marriage counseling units are established in the communities that make up the Local Government Areas, the units should make use of qualified psychologists and social workers. Finally, bill boards showing the dangers of wife battering should be mounted by community leaders, Churches, NGOs and well-meaning individuals in the society. Such bill boards should not attract payment of taxes to the LGA authorities.

\section{DECLARATION OF CONFLICT OF INTEREST}

The author(s) declare no conflict of interest in the research, authorship, and/or publication of this article.

\section{FUNDING}

The author(s) received no financial support for the research, authorship, and/or publication of this article.

\section{REFERENCES}

Abayomi, A. A., \& Olabode, T. (2013). Domestic violence and death: women as endangered gender in Nigeria. American Journal of Sociology Research, 3(3), 53 - 60.

Abbasi, S. S., Akram, M. B., \& Manzoor, B. (2015). Impact of wife battering on the family. Mediterranean Journal of Social Sciences, 6(4), 344-353. https://doi.org/10.5901/mjss.2015.v6n4s1p344

Ajah, B. O, Uwakwe, E. E., Nwokeoma, B. N., Ugwuoke C. O., \& Nnnamani, R. G. (2020). Ameliorating the plight of awaitingtrial inmates in Ebonyi State, Nigeria through reasonable bail condition. Pertanika Jounal of Social Sciences \& Humanities, 28 (4), $2897-2911$

Ajah, B. O. (2018). Educational training of inmates in Awka and Abakaliki Prisons, Nigeria Journal International Journal of Criminal Justice Sciences. 13 (2), 299-305

Ajah, B. O., \& Okpa, J. T. (2019). Digitization as a solution to the problem of awaiting-trial inmates in Ebonyi State, Nigeria. International Journal of Criminal Justice Sciences, 14 (2), 199-207.
Ajah, B. O., \& Ugwuoke, C. O. (2018). Juvenile Justice Administration and Child Prisoners in Nigeria. International Journal of Criminal Justice Sciences, 13 (2), 438-446.

Ajah, B.O., Ajah, A.I., \& Obasi, C. O. (2020). Application of Virtual Reality (VR) and Augmented Reality (AR) in the Investigation and Trial of Herdsmen Terrorism in Nigeria. International Journal of Criminal Justice Sciences, 15 (1), 1-20.

Ajah, B.O., Dinne, C.E., \& Salami, K. K. (2020). Terrorism in Contemporary Nigerian Society: Conquest of Boko-Haram, Myth or Reality. International Journal of Criminal Justice Sciences, 15 (1), 312-324.

Ajah, O. B., \& Onyejegbu, D. C. (2019). Neo-Economy and Militating Effects of Africa's Profile on Cybercrime. International Journal of Cyber Criminology, 13 (2), 326-342.

Ajayi, L. (2015). Socio-cultural factors of gender roles in women"s health care Utilization in Southwest Nigeria. Open Journal of Social Sciences, 3(2), 105-117.

Albert, I. O., Awe, T., Herault, G., \& Omitoogun, W. (2013). Informal channels for conflict resolution in Ibadan, Nigeria. Retrieved 20th February, 2015, from books.openedition.org/ifra/718.

Anderson, K. L. (1997). Gender, status and domestic violence : an integration of feminist and family violence approaches. Journal of Marriage and Family 59, 655 -669. https://doi.org/10.2307/353952

Anthony, E.O., Obasi, C.O., Obi, D.O., Ajah, B.O., Okpan, O.S., Onyejegbu, C.D., Obiwulu, A. C., \& Onwuama, E. M. (2021). Exploring the reasons for perennial attacks on churches in Nigeria through the victims' perspective. HTS Teologiese Studies/Theological Studies, 77(1), a6207. https://doi.org/10.4102/hts.v77i1.6207

Areh, C. E., Onwuama, E. M., \& Ajah, B. O. (2020). Social consequences of wife-battering in Ogbaru and Onitsha north local government areas of Anambra State, Nigeria. FWU Journal of Social Sciences, 14 (4), 80-92.

Charles, J. O. (2010). Sociological theory: a historic - analytical approach on man and society $\left(2^{\text {nd }}\right.$ ed.). Lagos: Serenity Publishers.

CPCVAWDV (2005). Council of Europe Convention on preventing and combating violence against women and domestic violence. Retrieved 18th June, 2015, from http://conventions.coe.int/treaty/en/reports/html/210.htm

Ebisi, N. (2016). The challenge of peace and conflict resolution a cluefrom Igbo cultural group. International Journal of Arts Humanities and social science, 1(4), 50-62.

Emegwa, L.O., Lawoko, S., \& Jansson, B. (2016). Attitudes towards physical intimate partner violence against women in Nigeria. Retrieved from http://us.sagepup.com/nam/openacess-atusage

Eze, O. J., Obi, D. O., \& Ajah, B. O. (2020). Nigerian criminal justice system and victims of crime neglect in Enugu Urban. FWU Journal of Social Sciences, 14 (3), 41-53.

Eze, O.J., Ajah, B.O., Nwonovo, O. S., \& Atama, C.S. (2021).Health sector corruption and COVID-19 outbreak: evidence from Anambra and Enugu States, Nigeria. Journal of Contemporary African Studies, DOI:10.1080/02589001.2021.192112

Ezegbe, B. N., Anyanwu, J. I., Oyeoku, E. K., \& Abiogu, G. C. (2013).Social implications of wife battering: Need for counseling services. Indian Journal of Applied Research, $3(8), 50-53$

Ezeilo, J. (2013, January $6^{\text {th }}$ ). Abolish native laws that allow wife beating. Punch Newspaper, Retrieved from nwww.punching.com/feature/encounter/abolish-native-lawsthat-allow wife-beating-ezeilo/.

Fakunmoju, S. A., Bammeke, F.O., Oyekanmi, A.D., Temilola, S., \& George, S. (2016). Development, validity, and reliability analysis of beliefs about relationship violence against women 
scale and gender stereotypes and beliefs in Nigeria. International Journal of Asian Social Science, 6(1) 58-79. https://doi.org/10.18488/journal.1/2016.6.1/1.1.58.79

Gurmu, E., \& Endale, S. (2017). Wife beating refusal among women of reproductive age in urban and rural Ethiopia. Journal of BCM International Health and Human right, 17(6), 2-12. https://doi.org/10.1186/s12914-017-0115-5

Hassan, E.E., Seedhom, A. E., \& Mahfouz, E.M. (2016). Men's perception of domestic violence in rural Minia, Egypt. Journal of Preventive Medicine, 6, 106-114.

Igwe, B.O (2015). Overcoming cultural, traditional and religious beliefs and practices in understanding and combating domestic violence in Nigeria. International Journal of Innovative Research and Development, 4(13).

Kawu, I. M. (2013, $21^{\text {st }}$ August). Nigeria's troubling epidemic of rapes. Vanguard Newspaper, p33.

Krafsky, K., \& Jason, K. (2013). Facebook and your marriage. The University of Texas (United States of America) at Austin study. Retrieved $21^{\text {st }}$ August, 2014, from www.amazon.com/facebook-your-marriage jasonkrafsky/dp/B005X4EC14

Mayaki, V. O., \& Choji, R. (2011). Nigeria: wife battering. Retrieved from http://allafrica.com/stories/201108082458.html

Nnam, M. U., Ajah, B. O., Arua, C. C., Okechukwu, G., \& Okorie, C. O. (2019). The War must be Sustained: An Integrated Theoretical Perspective of the Cyberspace-Boko Haram Terrorism Nexus in Nigeria. International Journal of Cyber Criminology, 13 (2), 379- 395.

Nnam, M.U., Effiong, J.E., Iloma, D.O., Terfa, I.M., \& Ajah, B.O. (2021) Hazardous drinking and the dark triad: an antidote for manipulative behaviour among students. Current Psychology, 40(4), 1-7.

Nnamani, G.R., Ilo, K.O., Onyejegbu, D. C., Ajah, B.O., Onwuama, M. E., Obiwulu, A. C., \& Nzeakor, O. F. (2021). Use of Noncustodial Measure and Independent Monitoring Body as Panacea to Awaiting-Trial Problems in Ebonyi State, Nigeria. International Journal of Criminal Justice Sciences, 16 (1), 5163.

NPC, (2006). National Population Commission.

Nwabunike, C.A., \& Tenkorang, Y. E. (2015).Domestic and marital violence among three ethnic groups in Nigeria. Journal of Interpersonel Violence, 2 (6), 1-26.

Obiozor, W. E. (2013). Meaningful inclusion and involvement of men in the elimination and prevention of violence against mothers. Keynote presentation at the 2013 International Women's
Day, March 8, 2013, at Irene Menakaya School, OnitshaNigeria.

Okemgbo, C.N., Omidey, A. K., \& Odimegwu, C. O. (2002) Prevalence, patterns and correlates of domestic violence on selected Igbo communities of Imo State, Nigeria. African Journal of Reproductive Health, 6, 101-114. https://doi.org/10.2307/3583136

Olatunji, A. O. (2017). Socio-economic determinants of wife-battering among ever-married women in Somolu Local Government Area, Lagos, Nigeria. Bangladesh e-Journal of Sociology, 14 (2), 90-98.

Oli, P. N. (2012). Public perception on violence against women in urban and rural areas in Anambra State. An Unpublished thesis work presented at University of Nigeria, Nsukka.

Oli, P. N.; Igbo, E. U. M., \& Okoye, U. O. (2013). Perception of what acts constitute violence against women among adult residents of Onitsha metropolis, Anambra State, Nigeria. International Journal of Development Research, 3 (12), 021 . 026

Olumeri, F.D. (2015). Domestic violence against women in Nigeria European Journal of Psychological Research, 2(1), 9-11.

Onwe, F., Odio, C. E., \& Eze, A. C. (2019). Socio-cultural factors associated with wife beating in Nigeria: a review of key issues. Journal of Social Service and Welfare, (2),1-14.

Oyediran, K.A. (2016). Explaining trends and patterns in attitudes towards wife beating among women in Nigeria: analysis of 2003, 2008 and 2013 demographic and health survey data. Spring open access journal, 72(11), 1-25. https://doi.org/10.1186/s41118-016-0016-9

Slide, C. (2013). How to deal with a lying spouse financial infidelity in marriage. Retrieved 2nd January, 2015, from http://www.moneycrasher.com/lyingabout-money-is-breakingup- marriages.

Suaad, M. E. (2015). Attitude to and perceptions of Domestic violence against women in Arab community: A case study of Libyan Migrants in the UK. Unpublished $\mathrm{PhD}$ thesis from Department of Sociology, Manchester metropolitan university

Ugwuoke, C. O., Ajah, B. O., \& Onyejegbu, C. D. (2020). Developing patterns of violent crimes in Nigerian democratic transitions. Aggression and Violent Behavior, 53, 1-8. https://doi.org/10.1016/j.avb.2020.101457

Umeh, S., \& Akpede, D. (2012, December $\left.27^{\text {th }}\right)$. Wife battery and the Nigerian woman. Premium Times, p.1-4.

World Health Organization (2014). Violence by intimate partner. Retrieved 3rd March, 2015, from http://www.google.com.ng/ url?sa=t\&rct=j\&q=\&esrc=s\&source=web\&cd $=10 \&$

\begin{tabular}{lll}
\hline Received on 30-06-2021 & Accepted on 12-08-2021 Published on 23-08-2021
\end{tabular}

\section{https://doi.org/10.6000/1929-4409.2021.10.155}

(c) 2021 Edith et al.; Licensee Lifescience Global.

This is an open access article licensed under the terms of the Creative Commons Attribution Non-Commercial License (http://creativecommons.org/licenses/by-nc/3.0/) which permits unrestricted, non-commercial use, distribution and reproduction in any medium, provided the work is properly cited. 